\title{
Pengaruh Motivasi, Kepemimpinan, Kompetensi Terhadap Produktivitas Kerja Pegawai PT. PLN (Persero) Area Tanjungpinang
}

\author{
Tiurma Arta Uli, Winata Wira, Dodi Dermawan
}

Fakultas Ekonomi Universitas Maritim Raja Ali Haji, Tanjungpinang, Kepulauan Riau, Indonesia

\begin{abstract}
ABSTRAK: Penelitian ini bertujuan untuk mengetahui apakah motivasi, kepemimpinan dan kompetensi berpengaruh terhadap produktivitas kerja pegawaiPT. PLN(Persero) Area Tanjung pinang. Jenis data yang digunakan adalah data primer dan data sekunder yang diperoleh melalui wawancara, penyebaran kuesioner dan studi kepustakaan yang pengukurannya menggunakan skala likert dan diolahdengan program SPSS22. Teknik sampel menggunakan purposive sampling berjumlah 74 responden yang disebar kepada seluruh pegawai tetap PT.PLN (Persero) Area Tanjungpinang. Metode analisis data yang digunakan adalah analisis kuantitatif dengan menggunakan uji kualitas data, ujiasumsiklasik dan analisisregresi linear berganda. Hasil penelitian ini menunjukkan bahwa secara simultan motivasi, kepemimpinan dan kompetensi berpengaruh signifikan terhadap produktivitas kerja pegawai PT.PLN (Persero) Area Tanjungpinang. Pada pengujian secara parsial (uji t) motivasi tidak berpengaruh signifikan terhadap produktivitaskerja pegawai PT.PLN (Persero) Area Tanjungpinang. Kepemimpinan secara parsial berpengaruh signifikan terhadapproduktivitas kerja pegawai PT.PLN (Persero) Area Tanjungpinang. Kompetensi secara parsial tidak berpengaruh signifikan terhadap produktivitas kerjapegawai PT.PLN (Persero) Area Tanjungpinang.
\end{abstract}

Kata Kunci : Motivasi, Kepemimpinan, Kompetensi dan Produktivitas Kerja Pegawai.

\begin{abstract}
This study aims to determine whether motivation, leadership and competence affect the work productivity of employees of PT. PLN (Persero) Tanjung Pinang Area. The type of data used is primary data and secondary data obtained through interviews, questionnaires and literature studies whose measurements use a Likert scale and processed with the SPSS22 program. The sample technique used purposive sampling amounting to 74 respondents distributed to all permanent employees of PT PLN (Persero) Tanjungpinang Area. The data analysis method used is quantitative analysis using data quality test, classic test and multiple linear regression analysis. The results of this study indicate that simultaneously motivation, leadership and competence have a significant effect on the work productivity of employees of PT PLN (Persero) Tanjungpinang Area. In partial testing ( t test) motivation does not have a significant effect on the productivity of employees of PT PLN (Persero) Tanjungpinang Area. Partial leadership has a significant effect on the productivity of employees of PT PLN (Persero) Tanjungpinang Area. Partial competence does not have a significant effect on work productivity of PT. PLN (Persero) Tanjungpinang Area employees.
\end{abstract}

Keywords: Motivation, Leadership, Competence and Employee Work Productivity.

Email Address : tiurmaartauli@gmail.com 


\section{PENDAHULUAN}

Tingkat produktivitas setiap pegawai bisa berbeda-beda, ada yang tinggi atas juga rendah. Bergantung pada tingkat emampuan masing-masing dalam menjalankan tugasnya. Perusahaan perlu memperkuat fungsi motivasi agar setiap individu dalam organisasi perusahaan dapat memahami bahwa setiap pekerjaan yang dilakukan member dampak yang signifikan bagi kelangsungan perusahaan. Pentingnya motivasi bagi pegawai karena motivasi adalah dorongan dari dalam diri yang memengaruhi orang untuk melakukan sesuatu Pride et.al. sebagaimana dikutip (Sunardi \& Anita,2012: 139). Motivasi juga dapat berarti pemberian daya penggerak yang menciptakan kegairahan kerja seseorang, agar mereka mau bekerja sama, bekerja efektif dan terintegrasi dengan segala daya upayanya untuk mencapai kepuasan (Hasibuan, 2014 :95).

Kepemimpinan mengarahkan jalan pencapaian tujuan suatu perusahaan. Manajer tanpa hadirnya seorang pemimpin pada sebuah perusahaan akan bingung dalam melaksanakan tugasnya, begitu juga dengan pegawai akan kurang termotivasi dalam melaksanakan tugasnya tanpa adanya seorang pemimpin. Kepemimpinan yang sesuai dengan ketentuan perusahaanakan membantu perusahaan mendapatkan produktivitas tenaga kerja yang efektif. Dari data realisasi Key Performance Indicator (Indikator Pengukuran Kinerja) perspektif kepemimpinan PT.PLN (Persero) Area Tanjungpinang tahun 2016, bahwa pencapaian dari target yangditetapkan masih belummaksimal.

Kompetensi yang dimiliki oleh seorang pegawai sangat penting untuk menbantu para manajer dalam menciptakan nilai dan memberikan kontribusi terhadap strategi perusahaan. Sehingga perusahaan perlu memperhatikan kompetensi setiap pegawainya. Kompetensi yang dimiliki oleh setiap pegawai berbeda-beda, jadi kompetensi dapat digunakan sebagai kriteria utama untuk menentukan kerja pegawai. Apabila kompetensi tidak sesuai dengan kerja yang dimiliki seorang pegawai, maka produktivitas kerja yang diharapkan perusahaan tidak efektif dan efisien.

Dengan begitu rumusan masalah dalam penelitian ini adalah motivasi, kepemimpinan, dan kompetensi mempengaruhi produktivitas kerja pegawai PT. PLN (Persero) Area Tanjungpinang. Sejalan dengan teori (Sedarmayanti,2009:72) yang mempengaruhi produktivitas kerja diantaranya adalah:sikap mental, berupa: motivasi, disiplin dan etika kerja, pendidikan, keterampilan, manajemen, hubungan industrial pancasila (H.I.P), tingkat penghasilan, gizi dan kesehatan, jaminan sosial,lingkungan dan iklim kerja, sarana produksi, teknologi dan kesempatan berprestasi. Sedangkan kepemimpinan (Winardi,2000: 55) sasaran umum seorang pemimpin dan kelompoknya adalah output yang dapat dinyatakan dalam bentuk produktivitas serta kepuasan.

\section{KAJIANTEORITIS}

\section{Faktor-Faktor Motivasi}

Ada beberapa factor motivasi menurut Siagian (2015:294) dalam teori kaitan imbalan dengan prestasinya baik yang bersifat internal maupun eksternal yaitu:

\section{Motivasi Internal}

Persepsi seseorang mengenai diri sendiri, harga diri, harapan pribadi, kebutuhan, keinginan, kepuasan kerja dan prestasi kerja yang dihasilkan.

\section{Motivasi Eksternal}

Jenis dan sifat pekerjaan, kelompok kerja di mana sesorang bergabung, organsiasi tempat bekerja, situasi lingkungan pada umumnya serta 
sistem imbalan yang berlaku dan cara penerapannya.

\section{Teori Kepemimpinan}

Ada beberapa teori kepemimpinan menurut Robbins \& Coulter (2010:147) diantaranya:

a. Teori-Teori Awal Kepemimpinan

Yaitu teori yang berfokus pada pemimpin (teori sifat) dan bagaimana Pemimpin berinteraksi dengan anggota kelompoknya (teori perilaku).

1. Teori sifat (Trait Theories) adalah teori dimana pemimpin yang memiliki kemauan untuk selalu mendorong pencapaian tujuan dengan cara yang dapat menginspirasi orang lain sehingga memperoleh hasil yang luar biasa.

2. Teori Perilaku (Behavioral Theories) adalah teori kepemimpinan yang mengidentifikasi perilaku yang membedakan antara pemimpin efektif dan tidak efektif.

b. Teori Kontingensi Kepemimpinan

Ada tiga teori kontingensi diantaranya:

1. Model Fiedlera dalah teori kepemimpinan yang menjelaskan bahwa kinerja kelompok yang efektif tergantung pada kesesuaian antara gaya kepemimpinan dan kendali serta pengawasan terhadap situasi.

2. Teori Kepemimpinan Situasi dikembangkan oleh Paul Hersey dan Ken Blanchard adalah teori kontingensi yang fokus terhadap kesiapan pengikutnya.

3. Teori Jalur-Tujuan (Path Goal Theory) dikembangkan oleh Robert

House adalah teori kepemimpinan yang menyatakan bahwa tugas pemimpin adalah membantu pengikutnya mencapai tujuan dan mengarahkan atau memberikan dukungan sesuai kebutuhan untuk memastikan bahwa tujuan mereka sejalan dengan tujuan kelompok atau organisasi. House mengidentifikasikan empat perilaku kepemimpinan :

- Pemimpin yang mengarahkan (directive leader) adalah pimpinan memberitahukan kepada bawahan apa yang diharapkan dari mereka, jadwal pekerjaan yang harus diselesaikan, serta memberikan bimbingan /arahan secara spesifik tentang cara-cara menyelesaikan tugas.

- Pemimpin yang mendukung (Suportive leader) adalah pemimpinyang menunjukkan kepedulian terhadap kebutuhan pengikutnya dan bersifat ramah.

- Pemimpin yang partisipatif (Participative leader) adalah pemimpinyang berkonsultasi dengan anggota kelompok dan menggunakan saran-saran danidemerekasebelummengamb il suatu keputusan.

- Pemimpin yang berorientasi prestasi (achievement-oriented leader) adalah pemimpin menetapkan sekumpulan tujuan yang menantang dan mengharapkan bawahanny auntuk berprestasi semaksimal mungkin.

\section{Model Kompetensi}

\begin{tabular}{llr}
\multicolumn{1}{c}{ Menurut $\quad$ Spencer dan } & Spencer \\
sebagaimana dikutip dalam Winanti & Wip \\
$(2011: 253)$ & Kompetensi & individual dapat \\
diklasifikasikan dalam tiga tingkatan, yaitu :
\end{tabular}

1. Kompetensi Intelektual adalah karakter sikap dan perilaku atau kemauan dan kemampuan intelektualindividu (dapat 
berupa pengetahuan, keterampilan, pemahaman profesional, pemahaman konseptual dan lain-lain) yangbersifat relative stabil ketika menghadapi permasalahan ditempat kerja,yang dibentuk dari sinergi antara watak dan konsep diri,motivasi internal,serta kapasitas pengetahuan konstektual.

2. Kompetensi Emosional adalah karakter tersikap dan prilaku atau kemauan dan kemampuan untuk menguasai diri dan memahami lingkungan secara objektif dan moral sehingga pola emosinya relative stabil dalam menghadapi permasalahan ditempat kerja,yang dibentuk darisinergi antara watak konsep diri, motivasi internal, serta kapasitas pengetahuan emosional.

3. Kompetensi Sosial adalah karakter sikap dan perilaku atau kemauan dan kemampuan untuk membangun simpulsimpul kerjasama dengan orang lain yang relative bersifat stabil ketika menghadapi permasalahan ditempat kerja yang terbentuk melalui sinergi antara watak, konsep diri, motivasi internal serta kapasitas pengetahuan social konseptual.

\section{Pengukuran Produktivitas Kerja}

Menurut Sutrisno(2009:111) Indikator untuk mengukur produktivitas kerja diantaranya:

1. Kemampuan Kerja Keterampilan dalam menyelesaikan pekerjaan, penguasaan pekerjaan, pemahaman dalam melakukan pekerjaan

2. Meningkatkan hasil yang dicapai Keinginan untuk melaksanakan pekerjaan, kesediaan untuk bekerja sama, pemberian motivasi dari pimpinan.

3. Semangat Kerja. Pencapaian hasil kerja, kualitas pekerjaan, kesesuaian dengan target perusahaan.

4. Pengembangan Diri
Keinginan meningkatkan kemampuan kerja, memiliki harapan yang baik dalam bekerja.

5. Mutu, Meningkatkan mutu yang lebih baik dan memberikan hasil yang terbaik.

6. Efisiensi, Ketepatan pekerjaan, penghematan sarana kerja, kesesuaian dengan jumlah jam kerja.

\section{Kerangka Pemikiran}

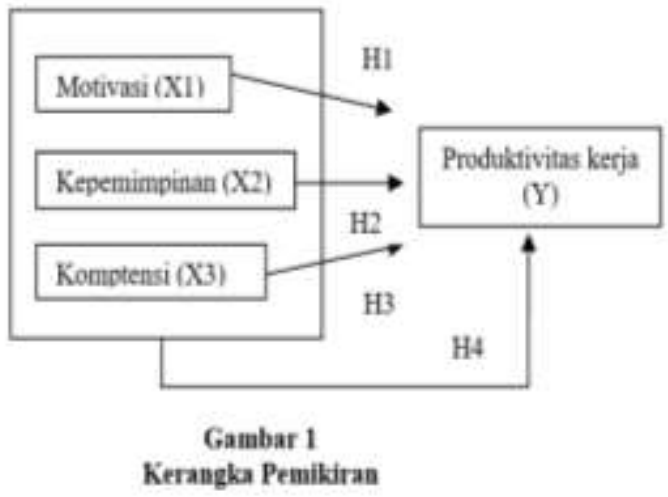

\section{Pengembangan Hipotesis}

Adapun hipotesis dari penelitian yang dilakukan berdasarkan permasalahan adalah sebagai berikut:

\section{Pengaruh Motivasi Terhadap Produktivitas Kerja Karyawan}

Menurut Hasibuan(2014:126) motivasi penting karena dengan motivasi ini diharapkan setiap individu karyawan mau bekerja keras dan antusias untuk mencapai produktivitas kerja tinggi. Hal ini didukung dalam penelitian terdahulu Mulyadi (2010) motivasi kerja memilki pengaruh yang positif terhadap produktivitas kerja sebesar $19.94 \%$.

H1 : Motivasi Secara Parsial Berpengaruh Signifikan Terhadap Produktivitas Kerja PegawaiPT. PLN(Persero) Area Tanjungpinang.

\section{Pengaruh Kepemimpinan Terhadap Produktivitas Kerja Karyawan}

Sebagaimana dikutip dalam Sunardi \& Anita (2012:158) produktivitas Yang tinggi 
merupakan harapan setiap manajer. Maka dapat disimpulkan bahwa pemimpin yang berorientasi pada kinerja akan meningkatkan produktivitas kerja karyawan. Dari penelitian Rumondor (2013) kepemimpinan berpengaruh positif tetapi tidak signifikan terhadap produktivitas kerja.

H2 : Kepemimpinan Secara Parsial Berpengaruh Signifikan Terhadap Produktivitas Kerja Pegawai PT. PLN(Persero) Area Tanjungpinang.

\section{Pengaruh Kompetensi Terhadap Produktivitas Kerja Karyawan}

Dalam penelitian terdahulu Bramanthi (2016) bahwa kompetensi bernilai Positif terhadap peningkatan produktivitas karyawan. Menurut Harris dalam Mulyadi(2010) kompetensi merupakan pengetahuan dasar pokok, kemampuan, pengalaman, dan persyaratan yang diperlukan untuk melaksanakan pekerjaan dengan sukses.

H3 : Kompetensi Secara Parsial Berpengaruh Signifikan Terhadap Produktivitas Kerja Pegawai PT. PLN(Persero) Area Tanjungpinang.

\section{Pengaruh Motivasi, Kepemimpinan dan Kompetensi Terhadap Produktivitas Kerja Karyawan}

Menurut penelitian terdahulu Rumondor (2013) motivasi dan kepemimpinan berpengaruh positif tetapi tidak signifikan terhadap produktivitas kerja. Sedangkan dalam Manalu et.al.(2014) bahwa motivasi, kepemimpinan, dan disiplin kerja secara parsial berpengaruh signifikan terhadap produktivitas kerja pegawai. Dari hasil penelitian Mulyadi(2010) motivasi kerja dan kompetensi kerja berpengaruh positif terhadap produktivitas kerja karyawan.

H4 : Secara Simultan Motivasi, Kepemimpinan dan Kompetensi Berpengaruh Signifikan Terhadap Produktivitas Kerja Pegawai PT.PLN(Persero) Area Tanjungpinang.

\section{METODOLOGI PENELITIAN}

\section{Lingkup Penelitian}

Objek penelitian ini adalah seluruh pegawai yang bekerja di PT. PLN (Persero) Area Tanjungpinang.Dalam penelitian ini melalui pengajuan angket atau kuesioner kepada pegawai PT. PLN(Persero) Area Tanjungpinang. Penelitian ini menggunakan sampel dari populasi dan menggunakan kuesioner sebagai alat pengumpulan data yang bersumber dari HRD (Human Resource Department) PT.PLN (Persero) Area Tanjungpinang dengan menggunakan SPSS (Statistik Package Social Sciences) 22.

Jenis penelitian ini adalah penelitian kuantitatif karena data penelitian berupa angka-angka, kemudian data yang diperoleh dianalisis dengan uji statistik untuk membantu menganalisis data kegiatan perhitungan statistic menggunakan program

\section{Operasional Variabel Penelitian \\ Produktivitas kerja (Y)}

Produktivitas kerja pegawai diukur dengan enam indicator (Sutirsno,2009: 111) yakni kemampuan kerja, hasil kerja, semangat kerja, pengembangan diri,mutu dan efisiensi. Berdasarkan jawaban responden yang menggunakan skala likert 1 (Sangat tidak setuju) sampai dengan (sangat Setuju) pada delapan buah pernyataan yang dikembangkan oleh Faeri (2015).

\section{Motivasi (X1)}

Motivasi adalah suatu kekuatan potensial yang ada di dalam diri seseorang manusia,yang dapat dikembangkannya sendiri atau dikembangkan oleh sejumlah kekuatan luar (Winardi,2008:6). Diukur dengan dua indicator (Siagian,2009: 40) yakni motivasi internal dan eksternal. Berdasarkan jawaban responden yang menggunakan skala likert1 (sangat tidak setuju) sampai dengan 5 (sangat setuju) pada dua belas buah 
pernyataan yang dikembangkan oleh Putri (2015).

\section{Kepemimpinan (X2)}

Kepemimpinan merupakan proses memimpin sebuah kelompok dan mempengaruhi kelompok itu dalam mencapai tujuannya (Robbins \&Coulter,2010: 146). Diukur dengan tiga indicator (Robbins \& Coulter, 2010: 146) yakni kepemimpinan direktif, kepemimpinan suportif dan kepemimpinan partisipatif. Berdasarkan jawaban responden yang menggunakan skala likert1 (sangat tidak setuju) sampai dengan 5 (sangat setuju) pad a15 buah pernyataan yang dikembangkan oleh Ginting (2011).

\section{Kompetensi (X3)}

Kompetensi adalahlandasankarakteristik orang dan mengindikasikan cara berprilaku atau berpikir, menyamakan situasi, dan mendukung untuk periode waktu cukup lama Menurut spencer dan spencer sebagaimana dikutip (Wibowo, 2016:272). Diukur dengan tiga indicator (Winanti,2011:253) yakni kompetensi intelektual,kompetensi emosional dan kompetensi sosial.Berdasarkan jawaban

Responden yang menggunakan skala likert 1(sangat tidak setuju) sampai dengan 5 (sangat setuju) pada 10 buah pernyataan yang dikembangkan oleh Bramanthi (2016).

\section{Pengumpulan Data}

Menurut Siregar (2013 : 17) pengumpulan data adalah suatu proses pengumpulan data primer dan sekunder, dalam suatu penelitian pengumpulan data merupakan langkah yang sangat penting, karena data yang dikumpulkan akan digunakan untuk pemecahan masalah yang sedang diteliti atau untuk menguji hipotesis yang telah dirumuskan.

\section{Data Primer}

Dalam penelitian ini metode pengumpulan data yang digunakan adalah:

a. Wawancara
Menurut Sugiyono(2014: 137) wawancara digunakan sebagai teknik pengumpulan data apabila peneliti ingin melakukan studi pendahuluan untuk menemukan permasalahan yang harus diteliti, dan apabila peneliti ingin mengetahui hal-hal dari responden yang lebih mendalam dan jumlah respondennya sedikit atau kecil.

b. Kuesioner

Menurut Sugiyono (2014: 142) kuesione rmerupakan teknik pengumpulan data yang dilakukan dengan cara memberi seperangkat pertanyaan atau pernyataan tertulis kepada responden untuk dijawabnya. Jenis kuesioner yang digunakan dalam penelitian ini kuesioner tertutup dalam penerapan skala likert.

Dalam Sugiyono (2014: 93) jawaban setiap item instrument yang menggunakan skal alikert mempunyai gradasi dari sangat positif sampai sanga tnegatif,yangdapat berupa katakata dan dapat diberi skor antara lain: SangatSetuju diberiskor 5, Setuju diberi skor 4, Netral diberi skor 3, Tidak Setuju diberi skor 2 dan Sangat Tidak Setuju diberi skor1.

\section{Teknik Penentuan Populasi dan Sampel}

Pengertian populasi menurut Bungin sebagaimana dikutip dalam Siregar (2013: 30) adalah keseluruhan dari objek penelitian yang dapat berupa manusia, hewan, tumbuhtumbuhan, udara gejala, nilai, peristiwa, sikap hidup dan sebagainya. Populasi penelitian ini adalah seluruh pegawai PT.PLN(Persero) Area Tanjungpinang. Adapun jumlah populasi dalam penelitian ini adalah 74 orang pegawai tetap.

Menurut Siregar (2013:30) sampel adalah suatu prosedur pengambilan data di mana sebagian populasi saja yang diambil dan dipergunakan untuk menentukan sifat serta ciri yang dikehendaki dari suatu populasi. Dalam penelitian ini teknik pengambilan sampel yang digunakan adalah 
nonprobability sampling. Menurut Sugiyono (2012: 66) nonprobability sampling adalah teknik pengambilan sampel yang tidak memberi peluang/kesempatan sama bagi setiap unsure atau anggota populasi untuk dipilih menjadi sampel. Teknik sampel ini meliputi, sampling sistematis, kuota, aksidental, purposive, jenuh, snowball.

Teknik nonprobability sampling yang digunakan adalah sampel Jenuh. Menurut Sugiono (2012: 68) sampel jenuh adalah teknik penentua nsampel bila semua anggota populasi digunakan sebagai sampel.

Tabel.1

\section{Sampel Penelitian}

\begin{tabular}{|l|c|}
\hline \multicolumn{1}{|c|}{ Bag } & Jumlah \\
\hline Distribusi & 1 \\
\hline Pembangkit & 1 \\
\hline Transasksi Energi & 1 \\
\hline Pelayanan Pelanggan & 2 \\
\& Administarsi & 8 \\
\hline Perencanaan & 8 \\
\hline Pengadaan & \multicolumn{2}{|c|}{4} \\
\hline Total Jumlah & $\mathbf{7 4}$ \\
\hline
\end{tabular}

Sumber :data primer diolah 2017

\section{METODE ANALISIS}

\section{Uji Kualitas Data}

\section{Uji Validitas}

MenurutAzwar sebagaimana dikutip dalam Wibowo (2012:35) uji Validitas atau kesalahan adalah sejauhmana suatu alat ukur mampu mengukur apa yang ingin diukur.

2. Uji Reliabilitas

Menurut Azwar sebagaimana dikutip dalam Wibowo(2012:52) uji reliabilitas adalah istilah yang dipakai untuk menunjukkan sejauh mana suatu hasilpengukuran relatif konsisten apabila pengukuran diulangiduakaliatau lebih.

\section{Uji Asumsi Klasik}

1. Uji Normalitas

Menurut Wibowo

(2012:61)

ujinormalitas untuk mengetahui apakah Nilai residu (perbedaan yang ada) yang diteliti memiliki distribusi normal atau tidak normal.

\section{Uji Multikoliniearitas}

Menurut Wibowo (2012 :87) uji multikoliniearitas adalah dengan Melihat nilai masing-masing variable bebas terhadap variabel terikatnya yang dapat dilihat berdasarkan nilai VIF (Varianc eInflation Factor)

\section{Uji Heteroskedastisitas}

Menurut Wibowo (2012:93) uji heteroskedastisitas adalah keadaan dimana dalam model regresi terjadi ketidaksamaan varian variabel. Model regresi yang baik adalah tidak terjadi heteroskedastisitas.

\section{Model Regresi Linear Berganda}

Analisis ini bertujuan untuk mengetahui ada atau tidaknya pengaruh variable independen yaitu motivasi, kepemimpinan, dan kompetensi terhadap variabel dependen produktivitas kerja. Persamaan regresi berganda yang digunakan adalah :

$\gamma=\alpha+\beta_{1} \cdot \mathrm{X}_{1}+\beta_{2} \cdot \mathrm{X}_{2}+\beta_{3} \cdot \mathrm{X}_{3}+e$

\section{Pengujian Hipotesis}

1. Uji t

Menurut Wibowo (2012:135) uji statistikt secara parsial digunakan untuk mengetahui apakah secara parsial variabel independen berpengaruh signifikan atau tidak terhadap variable dependen.

2. Uji F

Menurut Wibowo(2012 : 135), uji f digunakan untuk menguji pengaruh variable independen secara bersama-sama terhadap variabel dependen. 
3. KoefisienDeterminasi

Menurut Wibowo (2012:135) analisis determinasi digunakan untuk mengetahui persentase sumbangan pengaruh variabel bebas secara serentak terhadap variable terikat.

\section{PEMBAHASAN}

\section{Karakteristik Responden}

Dalam penelitian ini jumlah responden yang dianalisis berjumlah 74 orang. Peneliti mendistribusikan kuesioner sebanyak 74 eksamplar pada PT. PLN (Persero) Area Tanjungpinang yakni kepada seluruh pegawai tetap. Identitas responden diklasifikasikan berdasarkan jenis kelamin, pendidikan terakhir, bagian, dan usia.

Dari 74 responden, jumlah responden lakilaki sebanyak 65 responden dan perempuan 9 responden. Pendidikan terakhir responden SMA (45 orang), DIPLOMA (15orang) dan SARJANA (14 orang). Umur responden 1726tahun (22 orang), 27-36 tahun (15 orang), 3746 tahun (14 orang) dan 47-56 tahun (23 orang). Responden berada di beberapa bagian yaitu: distribusi (13 orang), pembangkit (10 orang), transaksi energy (11 orang), pelayanan pelanggan dan administrasi umum (28 orang), perencanaan ( 8 orang) dan pengadaan (4 orang).

\section{HASIL ANALISIS DATA \\ Validasi}

Uji validitas digunakan untuk menguji sejauh mana ketetapan alat pengukur dapat mengungkapkan konsep gejala kejadian yang di ukuritem kuesioner dinyatakan valid apabila $r$ hitung $\mathrm{r}$ tabel (uji dua sisi dengan sig 0,050). Seluruh pernyataan pada setiap variable valid karena nilainya lebih besar dari $r$ tabel.

\section{Hasil Uji Reliabilitas}

Reliabilitas menunjukkan sesuatu pengertian bahwa suatu instrumen dapat dipercaya untuk di gunakan sebagai alat pengumpulan data karena instrument tersebut sudah baik. Suatu variabel dikatakan reliable jika memberikan nilai crobach alpha $(\alpha)>0,60$. Hasil pengujian realiabilitas masing- masing variable semua varibel mempunyai koefisien alpha diatas 0,60 sehingga dapat dikatakan semua konsep pengukur masing-masing variable dari kuesioner adalah reliabel.

\section{Hasil Uji Asumsi Klasik}

1. Hasil Uji Normalitas

Nilai signifikansi 0,200 dan nilainya diatas 0,05 . Hal ini berarti data tersebut berdistribusi normal.

2. Hasil Uji Multikolinearitas

Nilai VIF semua variable bebas dalam penelitian ini $<10$, menunjukkan model tidak terdapat gejala multikolinearitas bahwa tidak terdapat hubungan antar variabelbebas.

3. Hasil Uji Heteroskedastisitas

Nilai signifikansi masing-masing variable independen lebih besar dari0,05 Yang artinya tidak terjadi heteroskedastisitas pada masing-masing variabel independen.

\section{PEMBAHASAN}

Berdasarkan tabel 2 dapat diketahui persamaan regresi berganda sebagai berikut: Persamaan regresi tersebut mempunyai makna sebagai berikut:

1. Konstanta $=4,255$ artinya, apabila motivasi, kepemimpinan, dan kompetensi sama dengan nol, maka produktivitas kerja pegawai sebesar 4,255 .

Tabel 2

Hasil Uji Regresi Linear Berganda

\begin{tabular}{|c|c|c|c|c|}
\hline \multicolumn{2}{|c|}{ L } & \multicolumn{2}{c|}{$\begin{array}{c}\text { Unstandardized } \\
\text { Coefficients }\end{array}$} & $\begin{array}{c}\text { Standardized } \\
\text { Coefficients }\end{array}$ \\
\cline { 3 - 5 } \multicolumn{2}{|c|}{} & B & Std. Error & Beta \\
\hline \multirow{2}{*}{1} & (Constant) & 4.255 & & \\
\cline { 2 - 5 } & $\begin{array}{l}\text { Total_X1 } \\
\text { Total_X2 } \\
\text { Total_X3 }\end{array}$ & -.013 & .036 & -.019 \\
\cline { 2 - 5 } & .499 & .028 & .896 \\
\cline { 2 - 5 } & -.058 & .042 & -.075 \\
\hline
\end{tabular}

a. DependentVariable:Total_Y

Sumber: data diolah, 2017 
2. Koefisien $X 1=-0,013$, jika variable motivasi mengalami penurunan satu poin, sementara kepemimpinan di anggap tetap,maka akan mengalami penurunan produktivitas kerja pegawai sebesar 0,013 .

3. Koefisien $\mathrm{X} 2=0,499$, jika variabel kepemimpinan mengalami kenaikan sebesar satu poin,sementara kompetensi di anggap tetap, maka akan menyebabkan kenaikan produktivitas kerja pegawai sebesar 0,499 .

4. Koefisien $\mathrm{X} 3=-0,058$, jika variabel kompetensi mengalami penurunan sebesarsatu poin, sementara kepemimpinan dianggap tetap, maka akan menyebabkan penurunan produktivitas kerja pegawaisebesar 0,058 .

\section{Hasil Pengujian Hipotesis}

\section{Hasil Uji Signifikasi Parsial (uji t)}

Untuk memperoleh nilai $\mathrm{r}$ table $(\alpha / 2 ; n-$ k-1) yaitu nilai signifikan dibagi 2. Kemudian, jumlah responden dikurang jumlah variabel independen dikurang satu. Sehingga diperoleh perhitungan $(0,05 / 2 ; \quad 74-3$ $1)=(0,025 ; 70)$.Yang berarti nilai persentase 0,025 dan jumlah distribusit70. Jadi nilai $r$ tabel $=1,99444$.

\section{Pengaruh Motivasi Terhadap Produktivitas Kerja Pegawai}

Hasil penelitian menunjukkan bahwa motivasi berpengaruh tetapi tidak signifikan terhadap produktivitas kerja pegawai. Hal ini ditunjukkan dengan nilai thitung pada variabel motivasi adalah $-0,365<$ tabel $=1,99444$ dan nilai signifikasinya $0,716>0,05$, maka $\mathrm{H}_{0}$ diterima dan $\mathrm{H}_{\mathrm{a}}$ ditolak sehingga dapat dikatakan bahwa motivasi tidak berpengaruh signifikan terhadap produktivitas kerja pegawai PT.PLN (Persero) Area Tanjungpinang. Hal ini sangat bertolak belakang dengan penelitian yang diteliti oleh Bramanthi (2016) menyatakan bahwa motivasi berpengaruh

signifikan terhadap produktivitas kerja pegawai.

Motivasi yaitu motivasi internal dan eksternal tidak mempengaruhi produktivitas kerja pegawai PT. PLN(Persero) Area Tanjungpinang.

\section{Pengaruh Kepemimpinan Terhadap Produktivitas Kerja Pegawai}

Hasil penelitian menunjukkan bahwa kepemimpinan berpengaruh signifikan terhadap produktivitas kerja pegawai. Hal ini ditunjukkan dengan nilaithitung pada variable motivasi adalah $17,643>$ tabel $=1,99444$ dan nilai signifikasinya $0,000<0,05$, makaH0 ditolak dan $\mathrm{H}_{\mathrm{a}}$ diterima sehingga dapat dikatakan bahwa kepemimpinan berpengaruh terhadap produktivitas kerja pegawai PT.PLN (Persero) AreaTanjungpinang.Hal ini mendukung penelitian yang diteliti oleh Manalu et.al (2014) menyatakan bahwa kepemimpinan berpengaruh signifikan terhadap produktivitas kerja pegawai.

Dengan adanya kepemimpinan yaitu kepemimpinan direktif, suportif dan partisipatif yang dapa tmeningkatkan produktivitas kerja pegawai. Kepemimpinan juga mempunyai peran yang sangat penting untuk meningkatkan produktivitas kerja pegawai PT.PLN (Persero) Area Tanjungpinang.

\section{PengaruhKompetensi Terhadap Produktivitas Kerja Pegawai}

Hasil penelitian menunjukkan bahwa kompetensi berpengaruh signifikan terhadap produktivitas kerja pegawai. Hal ini ditunjukkan dengan nilai thitung pada variabel kompetensi adalah-1,396<ttabel= 1,99444 dan nilai signifikasinya 
0,167>0,05, maka H0 diterima dan Ha ditolak sehingga dapat dikatakan bahwa kompetensi tidak berpengaruh terhadap produktivitas kerja pegawai PT.PLN (Persero) Area Tanjungpinang.Hal ini bertolak belakang dengan penelitian yang diteliti oleh Bramanthi (2016)menyatakan bahwa kompetensi berpengaruh signifikan terhadap produktivitas kerja pegawai.

Dengan adanya kompetensi yaitu kompetensi intelektual, emosional dan sosial tidak mempengaruhi produktivitas kerja pegawai PT. PLN (Persero) Area Tanjungpinang.

\section{Hasil Uji F}

Menurut Wibowo (2012 : 133), Uji f digunakan untuk menguji pengaruh variable independen secara bersama-sama terhadap variabel dependen. Hasil perhitungan regresi secara simultan diperoleh sebagai berikut:

Tabel 3

Hasil Uji F secara Simultan ANOVA $^{a}$

\begin{tabular}{|l|l|c|c|c|r|r|}
\hline \multicolumn{2}{|l|}{ Model } & $\begin{array}{c}\text { Sum of } \\
\text { Saunac }\end{array}$ & df & $\begin{array}{c}\text { Mean } \\
\text { Sauna }\end{array}$ & F & Sig. \\
\hline \multirow{3}{*}{1} & Regressi & 1460.681 & 3 & 486.89 & 113. & .000 \\
\cline { 2 - 7 } & Residual & 299.603 & 70 & 4.280 & & \\
& Total & 1760.28 & 73 & & & \\
\hline
\end{tabular}

a. DependentVariable:Total_Y

b. Predictors:(Constant), Total_X3, Total_X2,Total_X1

Sumber : Lampiran output SPSS (2017)

Dari tabel diatas menunjukkan bahwa nilai Fhitung $=113,759>$ Ftabel $=2,73$ dan taraf signifikan $0,000<0,05$. Hal ini berarti hipotesis yang menyatakan bahwa secara simultan variabel motivasi, kepemimpinan, dan kompetensi mempunyai pengaruh yang positif terhadap produktivitas kerja pegawai. Hipotesis dalam penelitian ini menolak Ho. Dengan demikian berarti hipotesis 4,
(H4 : Motivasi, kepemimpinan, dan kompetensi berpengaruh signifikan terhadap produktivitas kerja pegawai PT.PLN (Persero) Area Tanjungpinang).

\section{Hasil Uji Koefisien Determinasi}

Menurut Wibowo (2012 : 135) analisis determinasi digunakan untuk mengetahui persentase sumbangan pengaruh variabel bebas secara serentak terhadap variable terikat.

Tabel.4

\section{Hasil Uji Koefisien Determinasi ModelSummary}

\begin{tabular}{|l|c|c|c|c|}
\hline & & & $\begin{array}{l}\text { Adjusted } \\
\text { R Square }\end{array}$ & $\begin{array}{l}\text { Std. Error of } \\
\text { the Estimate }\end{array}$ \\
\hline 1 & $.911^{\mathrm{a}}$ & .830 & .823 & 2.069 \\
\hline
\end{tabular}

a. Predictors:(Constant), Total_X3,Total_X2,

Total_X1

Sumber :Lampiran Output SPSS(2017)

Dari tabel 4 menunjukkan bahwa Adjusted R Square adalah sebesar 0,823 atau $82,3 \%$. Hal ini menunjukkan bahwa persentase sumbangan pengaruh variabel independen yaitu motivasi, kepemimpinan dan kompetensi terhadap produkrivitas kerja sebedar $82,3 \%$ atau variasi variabel bebas yang digunkaan dalam model mampu menjelaskan sebesar $82,3 \%$ variasi variabel independen. Sedangkan sisanya $17,7 \%$ dipenagruhi oleh variabel lain yang tidak dimasukkan dalam model penelitian ini

\section{KESIMPULAN}

Berdasarkan hasil penelitian dari pengaruh motivasi,kepemimpinan, dan kompetensi terhadap produktivitas kerja pegawai PT.PLN (Persero) Area Tanjungpinang maka dapat diambil kesimpulan sebagai berikut:

1. Secara parsial motivasi tidak berpenga ruh signifikan terhadap 
produktivitas kerja pegawai PT.PLN(Persero) AreaTanjungpinag. Hal ini tidak sesuai dengan hipotesis bahwa motivasi secara parsial berpengaruh signifikan terhadap produktivitas kerja pegawai.

2. Secara parsial kepemimpinan berpengaruh signifikan terhadap produktivitas kerja pegawai PT.PLN(Persero) Area Tanjungpinang. Hal ini sesuai dengan hipotesis bahwa kepemimpinan secara parsial berpengaruh signifikan terhadap produktivitas kerja pegawai PT.PLN (Persero) Area Tanjungpinang.

3. Secara parsial kompetensi tidak berpengaruh signifikan terhadap produktivitas kerja pegawai PT.PLN (Persero) Area Tanjungpinang. Hal ini tidak sesuai dengan hipotesis bahwa kompetensi secara parsial berpengaruh signifikan terhadap produktivitas kerja pegawai PT.PLN (Persero) Area Tanjungpinang.

4. Secara simultan menunjukkan bahwa motivasi, kepemimpinan, dan kompetensi mempunyai pengaruh signifikan terhadap produktivitas kerja pegawai PT.PLN(Persero) Area Tanjungpinang.Hal ini sesuai dengan hipotesis bahwa secara simultanmotivasi, kepemimpinan dan kompetensi berpengaruh signifikan terhadap produktivitas kerja pegawai

\section{SARAN}

Berdasarkan hasil penelitian dan kesimpulan diatas,maka diberikan saran sebagai berikut:

1. Dalam penelitian yang akan datang perlunya memperluas jangkauan objek penelitian,yang mana pada penelitian ini hanya mengambil objekpadaPT. PLN (Persero) Area Tanjungpinang.
2. Untuk peneliti yang akan dating perlu meningkatkan dan mengembangkan populasi dan sampel penelitian,sehingga data yang lebih kompleks dan dapat terbaca dengan mudah.

3. Berkaitan denga nvariabel penelitian kepemimpinan, atasan hendaknya memberikan masukan mengenai tugastugas bawahannya agar produktivitas kerja pegawai semakin meningkat serta tercapainya visi dan misiperusahaan

4. Untuk divisi HRD (Human Resource Department) PT.PLN (persero) Area Tanjungpinang diharapkan dapat memberikan perhatian dan dukungan yang lebih terhadap kompetensi pegawai, dalam bentuk pelatihandan pengembangan karir yang lebih baik lagi.

\section{DAFTAR PUSTAKA}

Bramanthi, P. R. (2016). Skripsi Pengaruh Kompetensi, Masa Kerja, dan innsentif Terhadap Peningkatan Produktivitas Karyawan Bagian Produksi PT. Alima Usaha Samudra. Sekolah Tinggi illmu Ekonomi Tanjungpinang.

Ginting,K.R.(2011).Skripsi: $\quad$ Pengaruh Kepemimpinan dan Motivasi Terhadap Kepuasan Kerja Karyawan Pada PT.Asam Jawa Medan.Universitas SumateraUtara.

Gomes,F.C.(2003).Manajemen Sumber Daya Manusia.Yogyakarta:C.V Andi Offset.

Hartatik, I. P. (2014).Buku Praktis Mengembangkan SDM. Yogyakarta: Laksana. Hasibuan. (2014). Organisasi dan Motivasi Dasar Peningkatan Produktivitas. Jakarta: PT Bumi Aksara.

Manalu, ElpisAnto, et.al. (2014). Pengaruh Motivasi, Kepemimpinan, dan Disiplin Terhadap Produktivitas Kerja Pegawai 
Dinas Kehutanan dan Perkebunan Kabupaten Tapanuli Tengah. Jurnal Bisnis dan Manajemen Eksekutif, UniversitasTerbuka.

Muchdarsyah Sinungan.(2009).Produktivitas Apa dan Bagaimana. Jakarta: PT Bumi Aksara.

Mulyadi,H.(2010).Pengaruh Motivasi dan Kompetensi Kerja Terhadap Produktivitas Kerja Karyawan Pada PT.Galamedia Bandung Perkasa. Jurnal Manajerial Vol.9 No. 17, Universitas Pendidikan Indonesia.

Putri, Dea Finika. (2015). Skripsi: Pengaruh Stres dan Motivasi Terhadap Kinerja Karyawan Pada PT. Bank Tabungan Negara Cabang Pemuda Medan Universitas Sumatera Utara.

P.Siagian, S. (2015). Manajemen Sumber Daya Manusia. Jakarta: PT. Bumi Aksara.

Rumondor,V.W.(2013). Motivasi, Disiplin Kerja, dan Kepemimpinan Terhadap Produktivitas Kerja Pada Badan Kepegawaian dan DIKLAT Daerah Minahasa Selatan. Jurnal EMBA, 1042 Universitas Sam Ratulangi Manado.

Serdamayanti. (2009). Sumber Daya Manusia dan Produktivitas Kerja. Bandung: CV. Mandar Maju.

(2013). Manajemen Sumber Daya Manusia, Reformasi Birokrasi, dan Manajemen Pegawai Negeri Sipil.Bandung: PTRefika Aditama.

$\begin{array}{ccr}\text { Siregar,S.(2013). } & \text { Metode } & \text { Penelitian } \\ \text { Kuantitatif. } & \text { Jakarta: } & \text { Kencana } \\ \text { Prenadamedia Group } & \end{array}$

Stephen P. Robbins, Mary Coulter. (2010). Manajemen .Jakarta: Erlangga. Sugiyono. (2012). Statistika Untuk Penelitian. Bandung: Alfabeta.

Kuantitatif, Kualitatif, dan R\&D.
Bandung: Alfabeta.

Sunardi, Anita Primastiwi. (2012). Bisnis Pengantar (Konsep, Strategi, \& Kasus). Jakarta: CAPS.

Sutrisno, E. (2009). Manajemen Sumber Daya Manusia. Jakarta: Kencana. Sutrisno, F. (2015). Skripsi: Pengaruh Motivasi dan Pengalaman Kerja Terhadap Produktivitas Kerja Karyawan Pada Hotel Plaza Tanjungpinang. Sekolah Tinggi Ilmu Ekonomi Tanjungpinang.

Tjutju Yuniarsih, Suwatno. (2016). Manajemen Sumber Daya Manusia Teori Aplikasi, dan Isu Penelitian. Bandung: Alfabeta.

Wibowo. (2016).Manajemen Kinerja Jakarta:PT Raja Grafindo Persada.

Wibowo, A. E. (2012). Aplikasi Praktis SPSS dalam Penelitian. Yogyakarta: Penerbit Gava Media

Winanti, M. B. (2011). Pengaruh Kompetensi Terhadap Kinerja Karyawan (Survei Pada PT. Frisian Flag Indonesia Wilayah Jawa Barat). Majalah Ilmiah UNIKOM, 19 Universitas Komputer Indonesia 